\title{
Subseafloor alteration of a modern mafic-volcaniclastic hosted seafloor massive sulfide deposit
}

\author{
Melissa O. Anderson ${ }^{1}$, MARK D. HANNINGTON ${ }^{2,3}$,
} TIMOTHY F. MCCONACHY ${ }^{4}$, JOHN W. JAMIESON ${ }^{5}$, THOR HANSTEEN $^{3}$, SVEN PETERSEN ${ }^{3}$

${ }^{1}$ University of Toronto, Toronto, Canada; melissao.anderson@utoronto.ca

${ }^{2}$ University of Ottawa, Ottawa, Canada

${ }^{3}$ GEOMAR Helmholtz Centre for Ocean Research Kiel, Germany

${ }^{4}$ Neptune Minerals, Inc., Waverton, NSW, Australia

${ }^{5}$ Memorial University of Newfoundland, St. John's, Canada

Seafloor massive sulphide (SMS) deposits have been studied for more than four decades; however, little is known about the third dimension of these hydrothermal systems owing to the fact that very few of them have ever been drilled. This study provides the first description of subseafloor processes within a large active submarine hydrothermal system developed entirely within permeable mafic volcaniclastic rocks, representing a potentially important modern analog of a well-known class of ancient VMS deposits with broad, semi-conformable alteration zones.

Geological mapping and core logging is integrated with a wide range of analytical techniques, including whole-rock geochemistry, detailed mineralogy, isotope analyses, and fluid inclusion microthermometry, in order to establish the alteration history. Alteration is distributed in broadly conformable zones, in order of increasing depth and temperature: (1) montmorillonite/nontronite; (2) nontronite + corrensite; (3) illite/smectite (I/S) + pyrite; (4) I/S + chamosite; and (5) chamosite + corrensite. $\delta^{18} \mathrm{O}$ and $\delta \mathrm{D}$ values of clay minerals confirm increasing temperature with depth, from $124^{\circ} \mathrm{C}$ to $256^{\circ} \mathrm{C}$, and seawater-dominated hydrothermal fluids at high water:rock ratios.

We propose that the pervasive alteration of the volcaniclastic units close to the seafloor coincided with a progressive increase in subseafloor temperatures parallel to the seabed, reaching temperatures high enough to form anhydrite within two meters of the seafloor, sealing off the permeability. Over-pressuring and fracturing of the sulfateand clay-cemented volcaniclastic rocks produced the pathways for higher-temperature fluids to reach the seafloor, leading to the formation of barite- and sulphide-rich chimneys and chimney mounds over an area of $\sim 77,000 \mathrm{~m}^{2}$. In ancient deposits, anhydrite is often not preserved, so this important process has been poorly documented. 